\title{
Application of wireless tracer GPRS riverbed scour monitoring for disaster warning
}

\author{
C.C. $\mathrm{Su}$ \\ Postdoctoral fellow, Dept. of Civil Engrg., National Chung Hsing University, Taiwan \\ H.C. Yang \\ Associate professor, Shu Te University, Kaohsiung, Taiwan
}

\begin{abstract}
River incision after long-term general scour due to the existence of river-crossing structures, always has a huge influence on riverbed stability and hydraulic structure safety. The severe short-term riverbed general scour, bridge and bend/levee scour, and scour downstream of a grade-control structure (GCS) occurs frequently, causing bridge failures, levee damages, and headcuttings during typhoon-induced floods in the intermittent rivers in Taiwan. For examples, bridge collapse and embankment damage events resulted in the loss of life and vehicles due to falling into rivers in 2008 and 2009. Now, the wireless tracer GPRS realtime scour monitoring technique has been developed to monitor bridge and general scour, bend and toe scour and scouring below GCSs in real time during high flows, with the approach trialled within a gravel-bed reach in the lower Dachia River during 2015. The result indicates that the proposed method has the potential to be used as a tool for the practical application of disaster warning for monitoring the safety of bridge and embankment.
\end{abstract}

KEYWORDS: field data, online GPRS real-time scour monitoring, wireless tracer, flood.

\section{INTRODUCTION}

An understanding of riverbed scouring during a flood is a major research topic for the riverbed regulation in the civil and hydraulic engineering. Hunt (2009) noted that $58 \%$ of 1502 documented bridge failures in the United States between 1966 and 2005 were caused by scour.

Figure 1 shows the typical types of scour in a river. A natural river can be divided into a perennial, ephemeral, and intermittent river according to the hydrograph feature (Stringer et al., 1998; Svec et al., 2005). Due to the effects of geography and hydrology, most of the rivers in Taiwan are intermittent rivers with a great disparity discharge and high sediment transport capacity ( $\mathrm{Su}$ and $\mathrm{Lu}, 2016$ ). $\mathrm{Su}$ and $\mathrm{Lu}(2013,2016)$ used the numbered-brick method to measure the maximum short-term general scour $\left(d_{g s}\right)$ during monsoon- or typhoon-induced floods for steep intermittent rivers $\left(S_{0}=0.1 \% \sim 1.1 \%\right)$ in Taiwan. Further, $\mathrm{Su}$ and $\mathrm{Lu}(2013,2016)$ indicated that the $d_{g s}$ value is usually extreme in the range $=1.2$ $\mathrm{m} \sim 6 \mathrm{~m}$, especially for a gravel-bed reach with a wide gradation in the bed material. However, these field data of $d_{g s}$ for the intermittent rivers in Taiwan were much greater than those in perennial rivers and ephemeral rivers in the literature ( $\mathrm{Su}$ and $\mathrm{Lu}, 2016$ ).

The main channels in intermittent rivers in Taiwan were significantly incised after bed degradation/ long-term general scour ( $\mathrm{Su}$ and $\mathrm{Lu}, 2013 ; 2016)$. Moreover, there is the potential for short-term general scour caused by the increasing vertical-mixing of flow during a flood. Extreme flood events with a high discharge and long duration to peak have a gradually increasing probability due to the hydrological factor in response to global warming in the world (Kunkel et al., 2013; Emanuel, 2013).

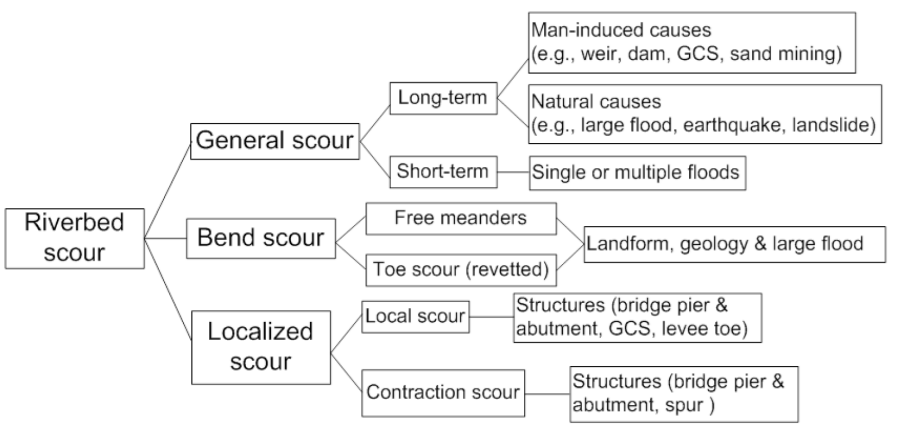

Figure 1. Typical types of scour in a river.

$\mathrm{Su}$ and $\mathrm{Lu}$ (2013) indicated that the extreme short-term general scour can be considered as a natural hazard event. Several bridge and embankment failure events were caused by hydraulic scour in the intermittent rivers in Taiwan, for example: (1) the Pier 2 collapse of the Houfeng Bridge in the Dachia River at flood peak during Typhoon Sinlaku in 2008, causing 6 deaths and the loss of 3 vehicles into the flood (Hong et al., 2012; Su and Lu; 2013); (2) the 
collapse of Piers 5 to 16 of the Shuangyuan Bridge in the Kaoping River at flood peak during Typhoon Morakot in 2009 (Wang et al., 2014; Wu et al., 2014), causing the falling of 12 people and 6 vehicles into the river; (3) damage to the embankment of the road between Shuili and Chichi by Typhoo Morakot-induced flood, resulting in 15 people and 7 vehicles falling into the Choshui River in 2009; and (4) the Shuideliaw Embankment was broken over a length of $200 \mathrm{~m}$ by Monsoon 610-induced flood in 2012 (with long flood peak duration= 60 h)(https://www.youtube.com/watch?v=Qzfo-CH3Zo; $\mathrm{Su}$ and $\mathrm{Lu}, 2016$ ).

Sheppard et al. (2014) indicated that the existing equilibrium scour equations usually overpredict bridge scour depths for larger structures due to largescale effects and without accurate flow event duration information for the prediction in a natural river. In fact, real-time field riverbed scour data are stilling lacking due to difficulties in undertaking in situ measurements without appropriate and efficient monitoring technique being available at this time. Practically, it is expected that there are only limited flood events each year.

$\mathrm{Su}$ and $\mathrm{Lu}$ (2013) found that an unusual, clockwise loop-rating curve (with discharge as abscissa) occurred due to the severe riverbed scouring during the process of high peak flow for a gravel-bed intermittent river. In other words, the water surface level raises slowly, but the flow discharge increased rapidly. The bridge closure based on the information obtained from the self-recording water level gauge failed due to the distortion water level. The relation between riverbed scour and geomorphic conditions during a high-flood event is complex. Therefore, real-time scour monitoring is essential to assess the mechanism of riverbed scour during floods.

The existing scour monitoring methods have been presented in the literature (Hunt, 2009; Prendergast and Gavin , 2014), such as physical devices: sounding rod ( $\mathrm{Lu}$ et al, 2008), sliding magnetic collar (SMC, Lu et al, 2008); magnetic devices: smart rock (Chen et al., 2014); pulse or wave devices: ADP/ADCP, sonar (Hayden and Puleo, 2011), ground penetrating radar (GPR, Anderson et al., 2007); electrical conductivity devices: time domain reflectometry (TDR, Yu and Yu., 2009); tilt sensor (Washer, 2010), fiber optic/ fiber bragg grating (FBG, Zarafshan et al., 2012), buried accelerometers (Gendaszek et al., 2013); float-out device: remote sensor (Briaud et al., 2011), wireless tracer (Yang and $\mathrm{Su}, 2015)$, etc.

The main objective of this paper was to develop a suitable real-time scour monitoring technique for extreme flood and scour conditions. The wireless tracer online GPRS system was proposed for the synchronous measurements of general scour, bridge scour, toe scour and scour downstream of a GCS during typhoon-induced floods in an intermittent river. For practical purpose, the float-out device method can be applied as a useful tool for field scour data collection and disaster warning during floods in natural rivers.

\section{SITE DESCRIPTION}

The Dachia River in central Taiwan was selected for the field study. The location map is shown in Figure 2. The river source is in the Central Mountains and the seaward end flows into the Taiwan Strait. Its drainage area and river length are about $1,236 \mathrm{~km}^{2}$ and $124 \mathrm{~km}$, respectively. Taiwan is often subjected to typhoons from the Pacific Ocean in the rainy.

The Dachia River is an intermittent river. For the water resource supply, the Shihkang Dam is located $23.4 \mathrm{~km}$ upstream the river mouth. The field site is downstream of the Shihkang Dam in the lower Dachia River. It is a bimodal gravel-bed river reach with a steep bed slope $\mathrm{S}_{0}=1.1 \%$, sediment median size $\mathrm{D}_{50}=96 \mathrm{~mm}$ and geometric standard deviation of sediment $\sigma_{\mathrm{g}}=19.96$. The scour potential of riverbed is usually high for a flood with a high peak or long peak duration ( $\mathrm{Su}$ and $\mathrm{Lu}, 2016$ ). Bridge and levee failures frequently occur due to river incision caused by long-term general scour $(\mathrm{Su}$ and $\mathrm{Lu}$, 2016).

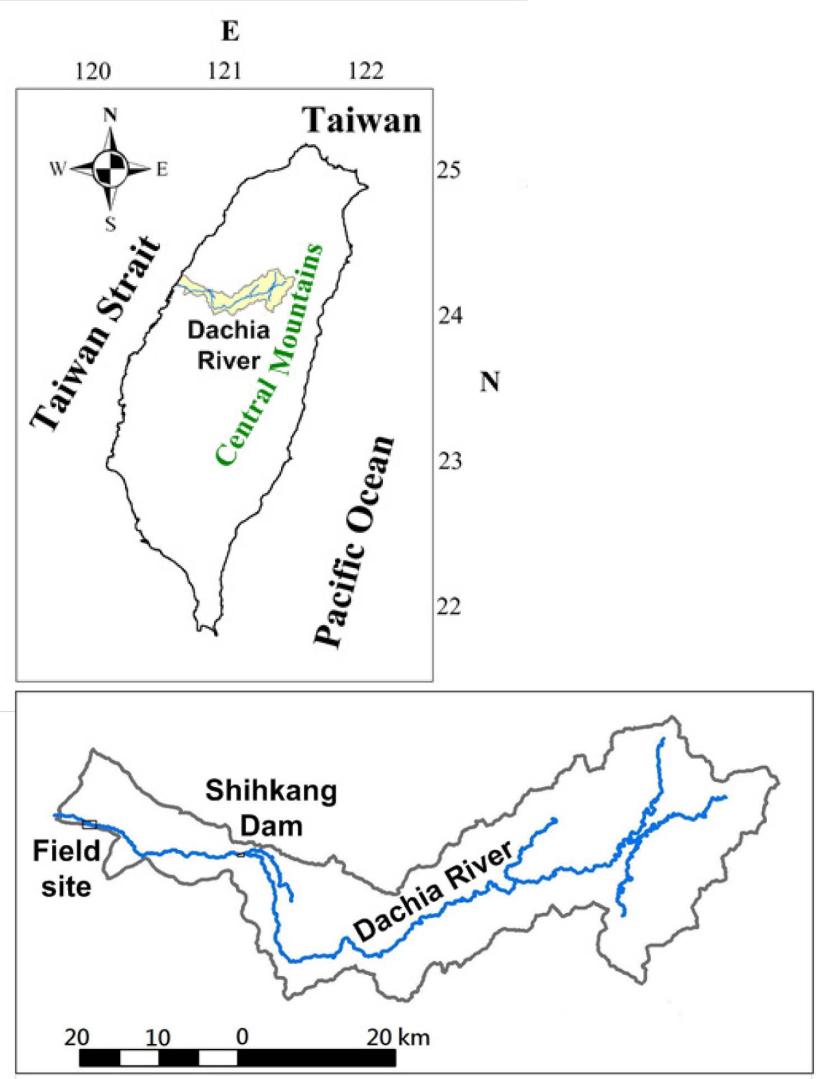

Figure 2. Field site map for the Dachia River. 


\section{METHOD}

\subsection{Wireless tracer GPRS real-time scour monitoring system}

The complete wireless tracer real-time scour monitoring system consists of (1) a mover end and (2) a monitor end.

(1) Mover end

Wireless tracers are float-out devices and must be embedded vertically into the riverbed in a low flow. A washed-out wireless tracer during the floodscouring process is a mover end. Yang and $\mathrm{Su}$ (2015) developed the $1^{\text {st }}$ version wireless tracer for real-time scour monitoring. It was based on a wireless communication principle. The self-designed circuit module of the $1^{\text {st }}$ version wireless tracer had 4 integer codes- $0,1,2$, and 3 . In current study, the self-designed circuit module of the $2^{\text {nd }}$ version wireless tracer has been upgraded to handle 256 integer codes- 0 to 255 and was adopted to provide a more efficient and accurate application, as shown in Figure 3(a). The specifics of the device are listed below:

- UHF band wireless data transceiver

- RD232-H wireless module $925 \mathrm{MHz}, 700 \mathrm{~m} \sim 2$ $\mathrm{km}$ monitored range,

- Self-designed handle 256 integer codes circuit module

- Independent coded float-out device with a height $12.5 \mathrm{~cm}$, diameter $9 \mathrm{~cm}$ plastic floating column

- General $9 \mathrm{~V}$ battery with magnet/mercury boot-up control when the device has been scoured out from the riverbed

The mercury boot-up control was trialled first as part of this study.

(2) Monitor end

The monitor end must be setup at the bridge or embankment downstream of the embedded monitoring position. The monitor end used in Yang and $\mathrm{Su}$ (2015) was the RF receiver software executed in a IBM-compatible PC or notebook, linking a USB interface wireless module. The received signals including time, numbered code, received signal strength indicator (RSSI), and time duration from starting can been recorded automatically in a Microsoft Excel file.

In the current study, an online GPRS real-time scour monitoring system has been developed for practical use, as shown in Figure 3(b). The RD232-H Com port wireless module was connected to the $\mu \mathrm{P}$ 4500-TC65 M2M (machine to machine) miniprogrammable automation controller for signal monitoring. A GPRS system can monitor several floating scoured-out wireless tracers for different riverbed measurement positions at a time during a flood.

The GPRS system was installed first downstream of the Highway Bridge at the rising limb during $1^{\text {st }}$ flood at 23:00 pm 5/26/2015.

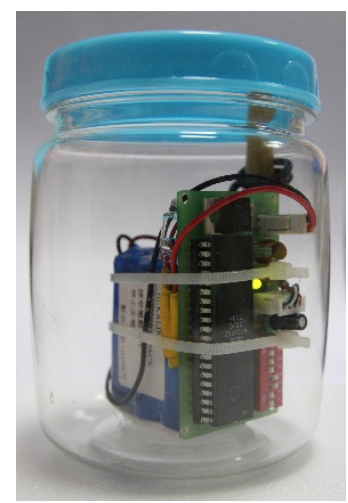

a

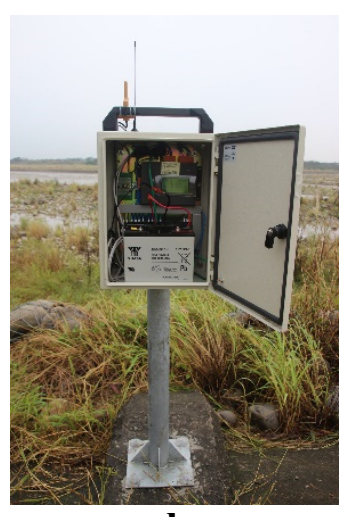

b
Figure 3. Wireless tracer GPRS real-time scour monitoring system (a) the mover end; (b) the monitor end installed at the Kerchuang Embankment in current study.

\subsection{Field scour measurements setup}

The gravel-bed reach of the lower Dachia River was selected as the main study site. The reach extends from upstream of the Formosa Super Highway Bridge to downstream of the Highway Bridge. Figure 4 shows the field study site together with the monitoring positions set up to monitor bridge and longitudinal general scour, bend scour and toe scour and scour below the GCS during high flows over a period of time.

The synchronous device setup for embedding numbered-bricks (length $=0.2 \mathrm{~m}$, width $=0.1 \mathrm{~m}$ and height $=0.055 \mathrm{~m}$ ) and wireless tracers (height $=0.15$ $\mathrm{m}$ and diameter $=0.09 \mathrm{~m}$ ) into the observed reaches still was applied on the field works. The highefficiency laying technique ( $\mathrm{Su}$ and $\mathrm{Lu}, 2013)$ is mainly based on devices consisting of a $5 \mathrm{~m}$ long hollow steel column and an $11 \mathrm{~m}$ long thin steel cable. At least two bricks must be used to weight the wireless tracer to counter buoyancy effect before souring out the riverbed.

Figure 5 shows the procedure of laying wireless tracer float-out devices at the P2 bridge scour monitoring position. The procedures of laying devices for the main channel in an intermittent river are as follows:

- Two excavators excavate a $5 \mathrm{~m}$ deep hole at the measurement position

- Numbered bricks and coded wireless tracers are placed order into the hollow steel column; a wireless tracer protected by two vertical numbered bricks

- $11 \mathrm{~m}$ long steel cable wrapped vertically around the steel column

- The steel column is lifted up and lowered into the hole

- The hole is infilled

- The steel cable is removed

- The hollow steel column is removed leaving the instruments inside the riverbed

- Measurement positions located by transit survey 
In total, 50 coded wireless tracers with numbered bricks were embedded vertically into seven prepared measuring locations near the main channel along the longitudinal river reach in the direction of the flow.
The vertical elevations of the embedded coded wireless tracers are shown in Figure 6. The cross-sections of the measurement positions $\mathrm{P} 1$ to $\mathrm{P} 7$ are shown in Figure 7.

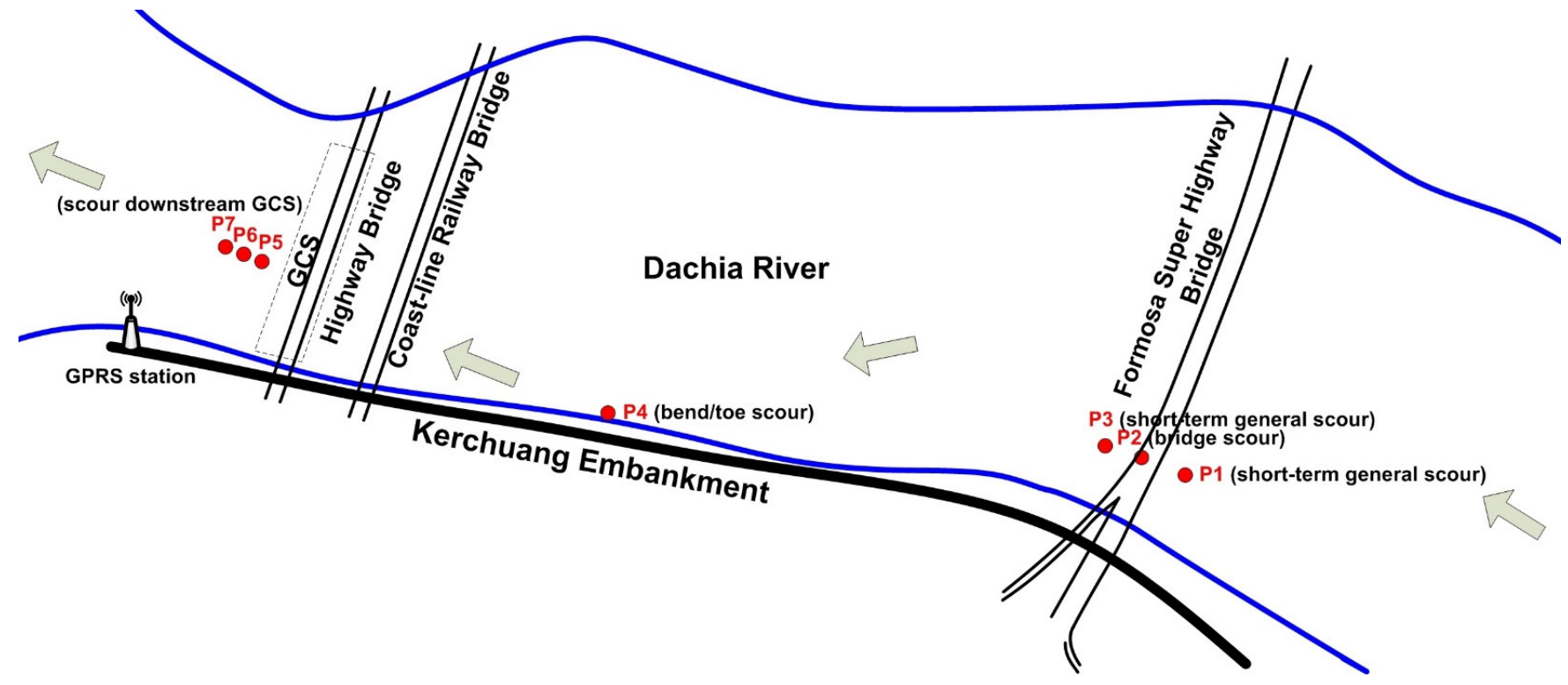

Figure 4. Schematic layout for wireless tracer GPPS real-time riverbed scour monitoring in the intermittent Dachia River in Taiwan.
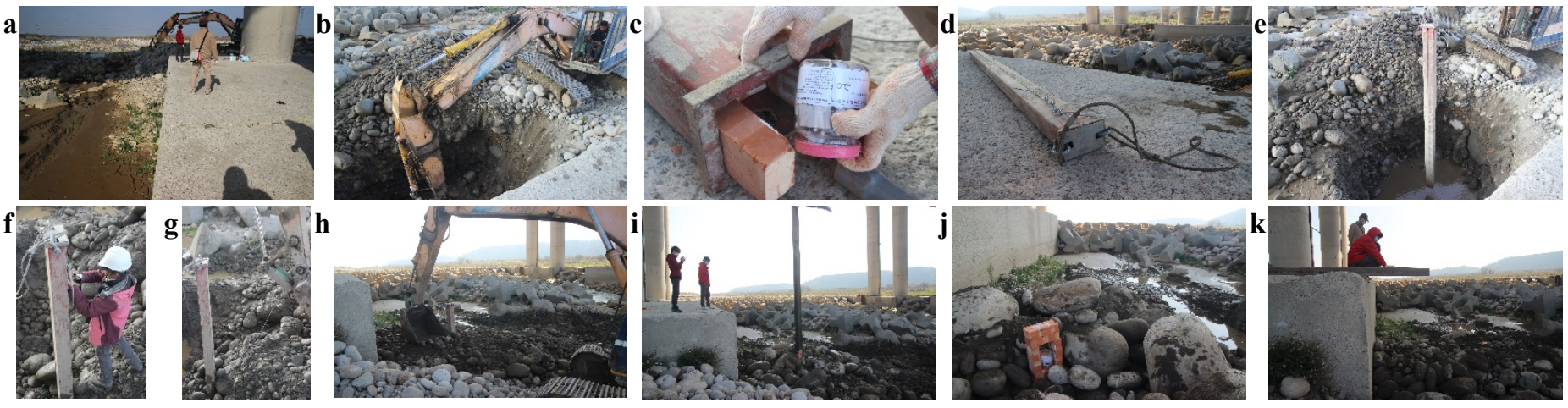

Figure 5. Laying devices procedures for P2 bridge scour monitoring at the Formosa Super Highway Bridge.
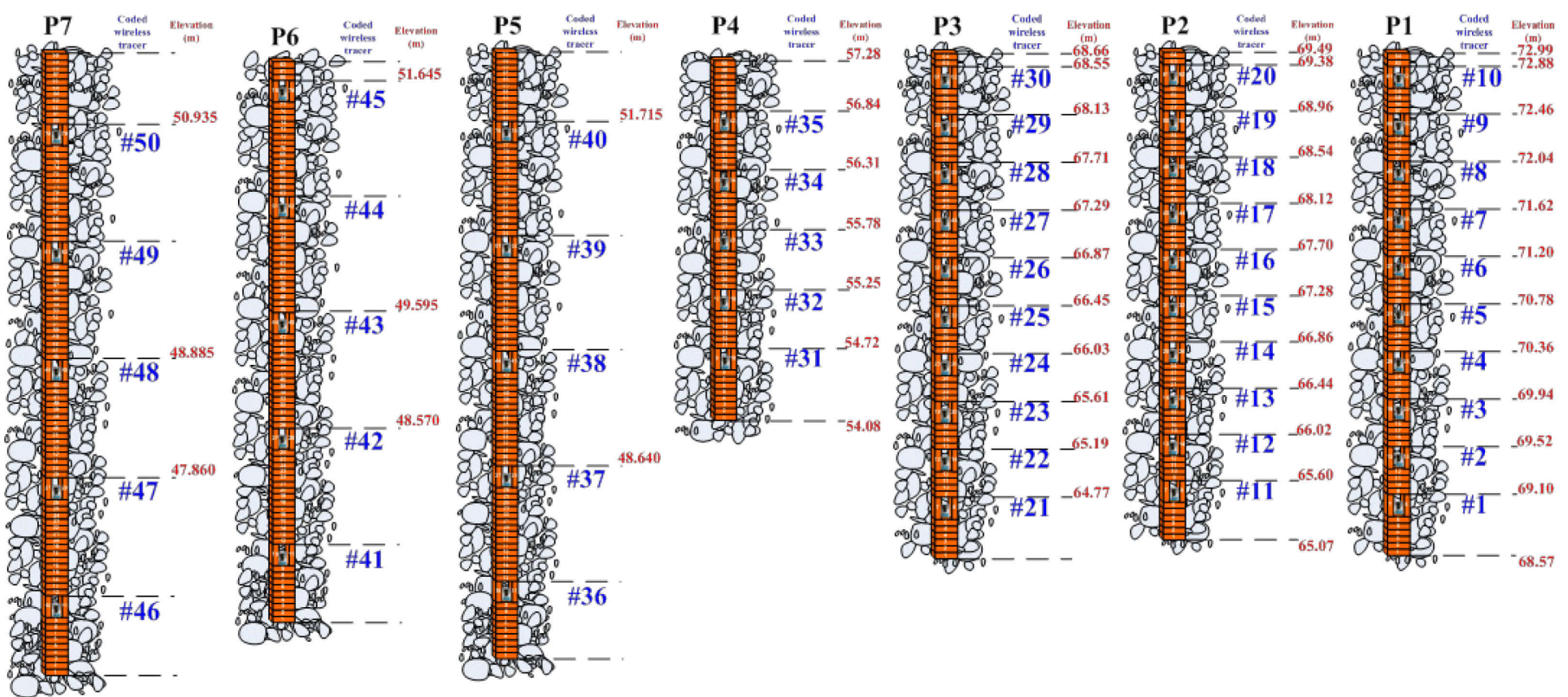

Figure 6. Vertical elevations of embedded coded wireless tracers for real-time riverbed scours monitoring. 


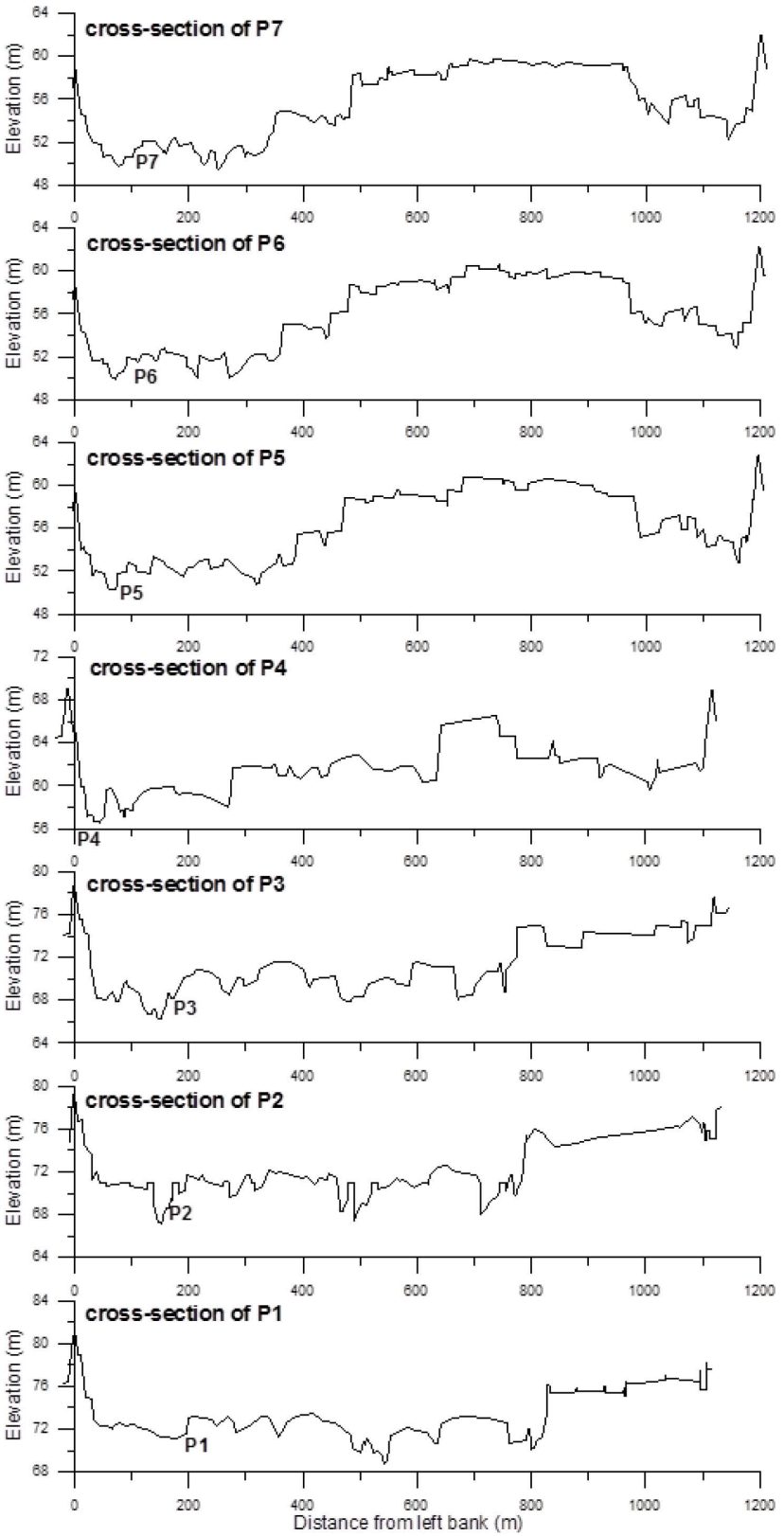

Figure 7. Cross-sections of measurement positions P1 to P7.

\section{RESULTS}

\subsection{Long-term general scour}

Bed degradation after long-term general scour is often caused by human activities such as the construction of hydraulic structures or by natural events such as earthquakes or extreme flooding in a river.

For example, Figure 8 shows the severe long-term general scour in the Dachia River in Taiwan. Between 1974 - 1993 the long-term general scour rate near the Houfeng Bridge $4.781 \mathrm{~km}$ downstream the Shihkang Dam (completed in 1977) was about 0.55 $\mathrm{m} / \mathrm{y}$. Certainly, the long-term general scour had significantly decreased after the riverbed degradation. The 1999 Earthquake (Richter magnitude 7.3) caused the uplifting of riverbed near the left-bank of Shihkang Dam by about $10 \mathrm{~m}$ (Hong et al., 2012). Between 1998 - 2013 the long-term general scour rate near the Houfeng Bridge was about $0.61 \mathrm{~m} / \mathrm{y}$. However, the Houfeng Bridge failure occurred dur- ing the typhoon-induced flooding in 2008, caused by Typhoon Sinlaku (Hong et al., 2012).

In addition, the corresponding long-term general scour rates of cross-section (CS) No.23, $454 \mathrm{~m}$ downstream of the Expressway No.1 Bridge (8.155 $\mathrm{km}$ downstream of the Shihkang Dam) for this dam and GCS of the bridge were $0.44 \mathrm{~m} / \mathrm{y}$ and $0.59 \mathrm{~m} / \mathrm{y}$, respectively.

The river incision has increased observably both the long-term and short-term general scour rates due to the decreasing channel width during the floods in the intermittent Dachia River $\left(\mathrm{B}^{-} \rightarrow \mathrm{q}^{+} \rightarrow\left(\mathrm{d}_{\mathrm{gs}}\right)^{+}\right)$.

Therefore, it is important to develop an effective real-time scour monitoring system to enable the extreme potential of the riverbed scour to be measured at the field site.

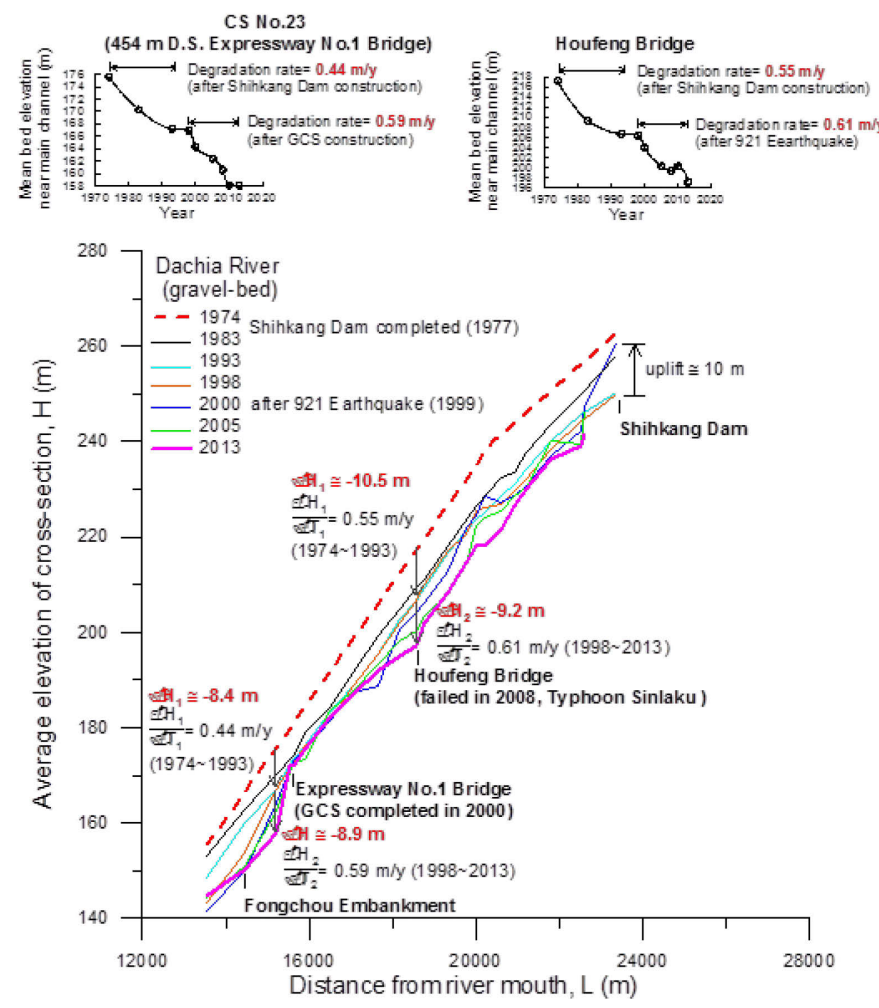

Figure 8. Long-term general scour caused by human activities and natural events for the Dachia River.

\subsection{Flood events}

The Highway Bridge is about $18 \mathrm{~km}$ downstream of the Shihkang Dam. The time of the peak flood at the study site occurs about $50 \mathrm{~min}$ at our file site after that at the peak flood occurs at the Shihkang Dam. In addition, there are no small tributaries flowing into this section of the river. The flow discharge hydrograph downstream of the Shihkang Dam was applied at our field site.

Table 1 lists the four flood events that occurred in the rainy seasons in the intermittent Dachia River during 2015. The maximum flood peak $\left(\mathrm{Q}_{\mathrm{p}}\right)$ was smaller than the dominant discharge $\mathrm{Q}_{2}$. The flood peak durations $\left(t_{p}\right)$ were short for those floods. Therefore, the riverbed scoured slightly during the rainy season. 
The flood flowed through the Formosa Super Highway Bridge and divided mainly into left and right currents. All sub-currents converged into single main channel near the Highway Bridge.

Table 1. Flood events for the Dachia River in 2015.

\begin{tabular}{cccc}
\hline $\begin{array}{c}\text { Flood events down- } \\
\text { stream Shihkang } \\
\text { Dam }\end{array}$ & Time of peak flow & $\begin{array}{c}\text { Flood peak } \\
\mathrm{Q}_{\mathrm{p}}\left(\mathrm{m}^{3} / \mathrm{s}\right)\end{array}$ & $\begin{array}{c}\text { flood peak du- } \\
\text { ration } \\
\mathrm{t}_{\mathrm{p}}(\mathrm{hr})\end{array}$ \\
\hline Monsoon 520 & $1: 00 \mathrm{am} \mathrm{5/27}$ & 801 & 6 \\
\hline Monsoon 624 & $19: 00 \mathrm{pm} \mathrm{6/24}$ & 877 & 2 \\
\hline Typhoon Soudelor & $19: 00 \mathrm{pm} \mathrm{8/8}$ & 683 & 3 \\
\hline Typhoon Dujuan & $7: 00 \mathrm{am} 9 / 29$ & 1,858 & 9
\end{tabular}

Note: dominant discharge $\mathrm{Q}_{2}=2,200\left(\mathrm{~m}^{3} / \mathrm{s}\right), \mathrm{Q}_{5}=3,800\left(\mathrm{~m}^{3} / \mathrm{s}\right)$ for the lower Dachia River

\subsection{Wireless tracer GPRS real-time scour monitoring}

The scoured riverbed elevation (corresponding Figure 6) and scour depth (riverbed surface level known before a flood) can be measured directly in the field and obtained on an online computer in an office or internet website from the GPRS system in real-time.

The wireless tracers were monitored using the online GPRS system during Monsoon 520 and Typhoon Dujuan-induced floods. A summary of the results is given below:

(1) Monsoon 520

Figure 9 shows the flow discharge hydrograph and the result of real-time scour monitoring during Monsoon 520-induced flood. Figures 10(a), (b) and (c) present the photgraphs of the flow condition around monitoring point P2 near the Formosa Super Highway Bridge at peak flood.

As shown in Figures 9, 11 and Table 2, the wireless tracer \#19 was scoured out from P2 measurement position and was monitored by the online GPRS system, i.e. indicating that the real-time bridge total scouring depth $\mathrm{d}_{\mathrm{bs}(\mathrm{P} 2)}=0.53 \mathrm{~m}$. Table 2 presents the monitoring information, including date, time, RSSI, and duration from boot-up. The mercury boot-up control was tested first, so the duration from boot-up was only short time.

A float-out device can obtain directly the correct scouring riverbed level (embedded top elevation in the riverbed) once when it is scoured out during a flood. The approximately continuous readings of bed level can be reached by the installation of more wireless tracers in a vertical in advance.

Figure 12 shows the field observation photos after recession. The left-current near the bridge flowed forward bend. As shown in Table 3, the results of deposited height during falling were 0 for P1, P2, and P3 measurement positions, then the maximum depths using by numbered-brick method were found as $\mathrm{d}_{\mathrm{gs}(\mathrm{P} 1)}=0.840 \mathrm{~m}, \mathrm{~d}_{\mathrm{bs}(\mathrm{P} 2)}=0.785 \mathrm{~m}$, and $\mathrm{d}_{\mathrm{gs}(\mathrm{P} 3)}=$ $0.475 \mathrm{~m}$, respectively.

Several scoured wireless tracers were not monitored during this flood. It might be caused by being too late to install the GPRS system in the field site.

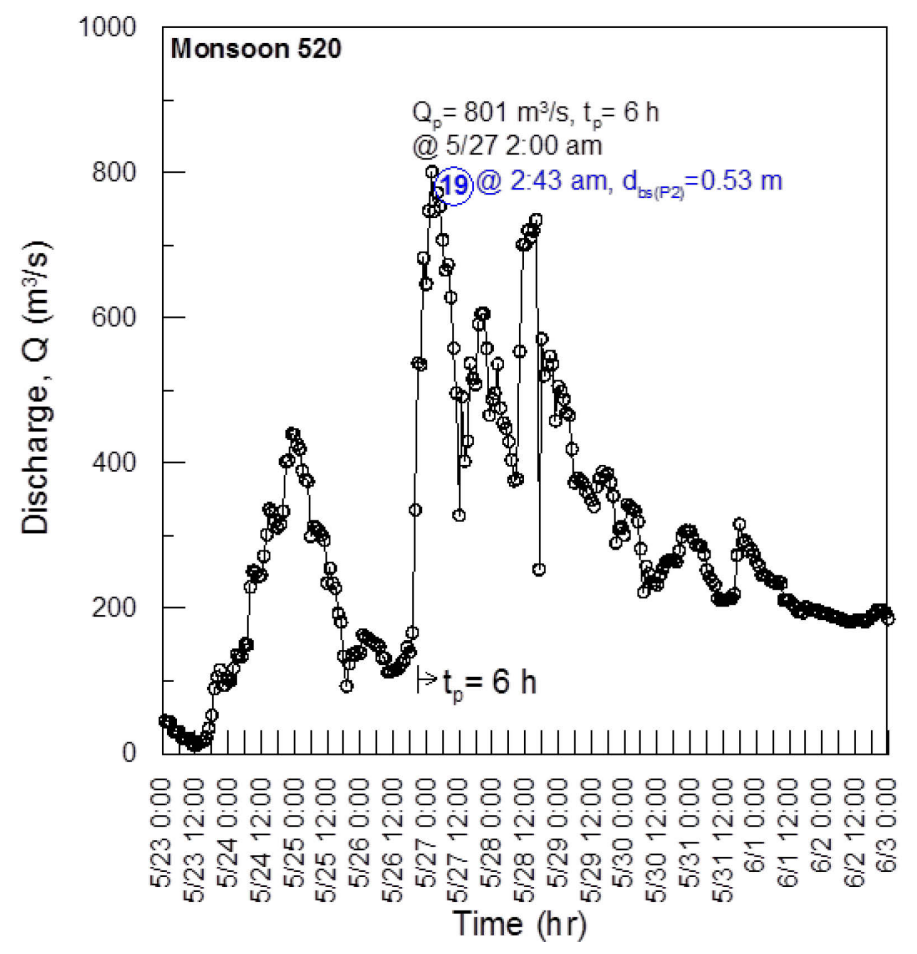

Figure 9. Flow discharge hydrograph and result of real-time scour monitoring during Monsoon 520-induced flood.
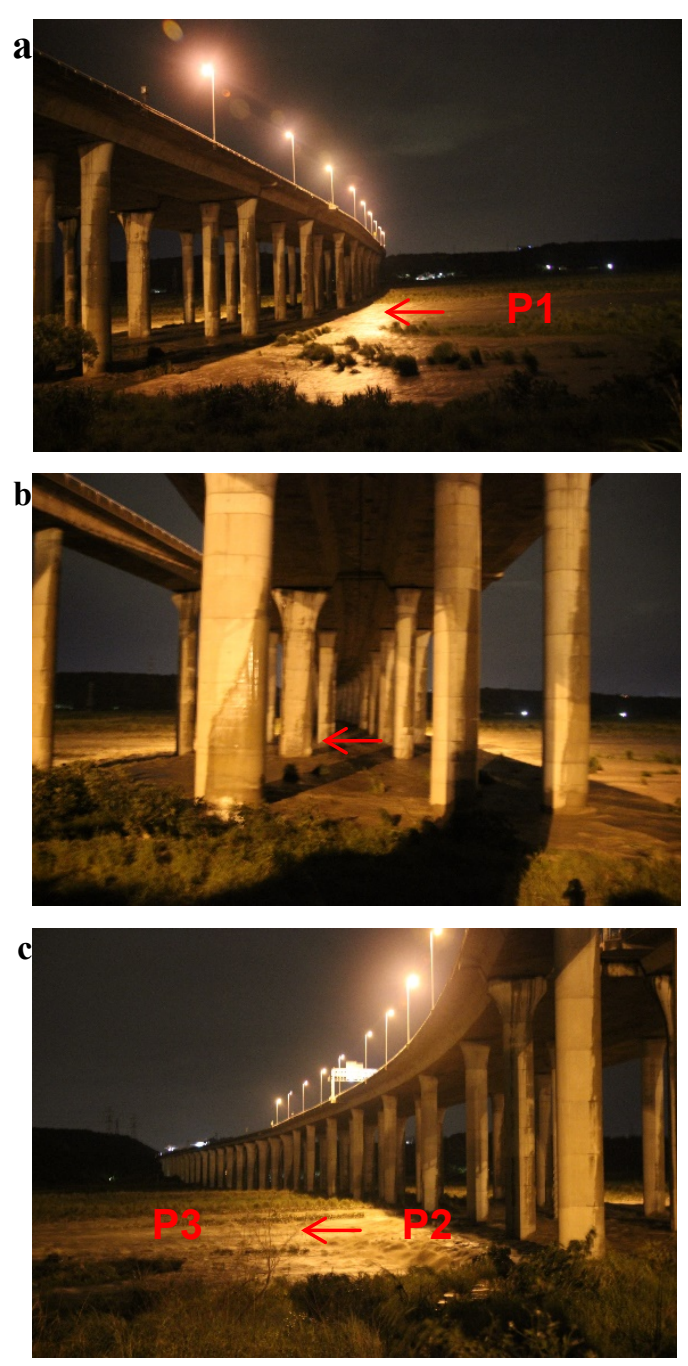

Figure 10. Flow condition near flood peak during Monsoon 520-induced flood: (a) upstream; (b) bridge piers; and (c) downstream of the Formosa Super Highway Bridge, photos by author at 01:45 am May 27, 2015. 


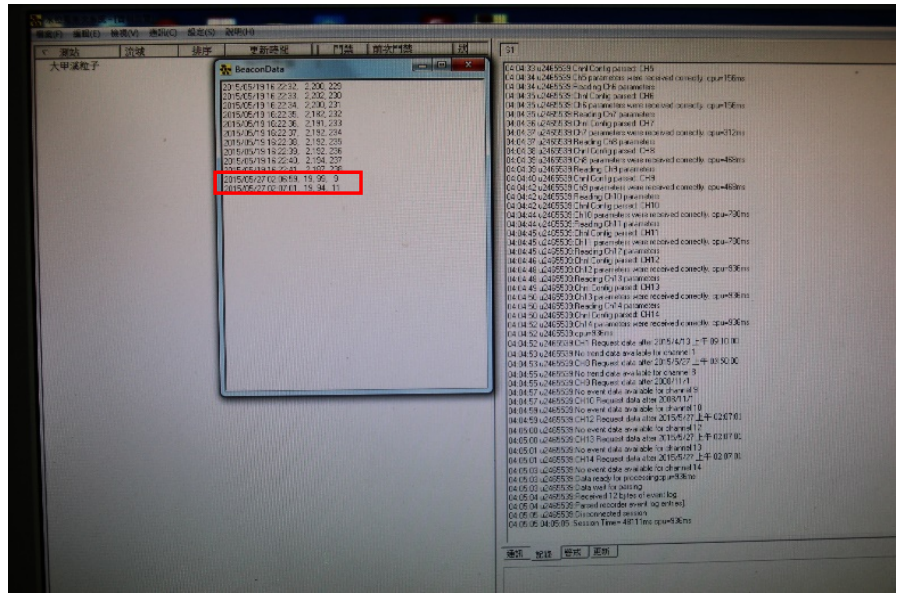

Figure 11. Result of GPRS real-time scour monitoring during Monsoon 520-induced flood.

Table 2. GPRS system monitored information during Monsoon 520 -induced flood.

\begin{tabular}{ccccc}
\hline date & time* & $\begin{array}{c}\text { wireless tracer } \\
\text { coded No. }\end{array}$ & RSSI & $\begin{array}{c}\text { Duration from } \\
\text { boot-up (sec) }\end{array}$ \\
\hline $2015 / 5 / 27$ & $02: 06: 59$ & 19 & 99 & 9 \\
\hline $2015 / 5 / 27$ & $02: 07: 01$ & 19 & 94 & 11 \\
\hline
\end{tabular}

Note: * time on GPRS system was delayed about $37 \mathrm{~min} 31 \mathrm{sec}$

(2) Typhoon Dujuan

Table 4 shows the variations of riverbed elevation for all measurement positions before Typhoon Dujuan. Figure 13 shows the flow discharge and real-time scour monitoring during Typhoon Dujuaninduced flood, i.e. the maximum flood peak in 2015.

The wireless tracers embedded at P1, P2, P3 (near the Formosa Super Highway Bridge), and P6 (downstream of GCS at the Highway Bridge) measurement positions were monitored immediately after being scoured out during the flood.

Figure 13 shows the flow discharge hydrograph and real-time scour monitoring during Typhoon Dujuan-induced flood. As shown in Figure 13, most riverbed scouring occurred at the rising limb. However, the wireless tracer \#44 (P6) was monitored at the falling limb, indicating the riverbed downstream of GCS was still scoured due to the limited sediment supply from the upstream reach. Figure 14 shows the comparison of the approach flow depth at the GCS/bridge and scour downstream of the GCS (P6 measurement position) at the Highway Bridge. The real-time scour depth for wireless tracers \#45 and \#44 were $0.165 \mathrm{~m}$ and $1.19 \mathrm{~m}$ during this flood, respectively.
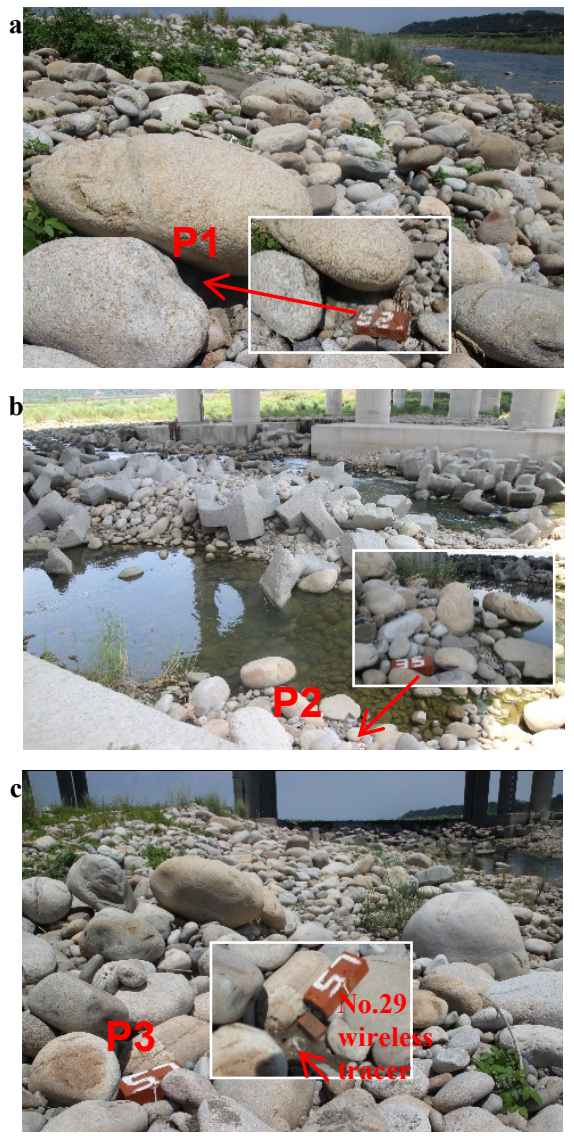

Figure 12. Field observations after recession (a) P1, (b) P2, (c) P3 measurement positions.

Table 3. Comparison of maximum scour measured by numbered-brick column and wireless tracer GPPS real-time riverbed scour monitoring at the Formosa Super Highway Bridge during Monsoon 520-induced flood.

\begin{tabular}{|c|c|c|c|c|c|c|c|c|c|c|c|c|c|c|}
\hline \multirow[b]{2}{*}{$\begin{array}{c}\text { Measurement } \\
\text { position } \\
\text { (scour type) }\end{array}$} & \multicolumn{2}{|c|}{ Location } & \multirow[b]{2}{*}{$\begin{array}{l}\text { Flood event } \\
\text { (time of } Q_{p} \text { ) }\end{array}$} & \multirow{2}{*}{$\begin{array}{c}\text { Flood peak } \\
\text { discharge } \\
\mathrm{Q}_{\mathrm{p}}\left(\mathrm{m}^{3} / \mathrm{s}\right) \\
\text { Flood peak } \\
\text { duration } \\
\left(\mathrm{t}_{\mathrm{p}}\right)\end{array}$} & \multirow{2}{*}{$\begin{array}{c}\text { (1) } \\
\begin{array}{c}\text { Preflood riverbed } \\
\text { level (top level of } \\
\text { numbered-brick) } \\
\text { (m) }\end{array}\end{array}$} & \multirow{2}{*}{$\begin{array}{c}\text { (2) } \\
\begin{array}{c}\text { Riverbed } \\
\text { level after } \\
\text { flood } \\
(\mathrm{m})\end{array}\end{array}$} & \multirow{2}{*}{$\begin{array}{l}\quad(3)=(2)-(1) \\
\\
\text { Difference of riv- } \\
\text { erbed level before } \\
\text { and after flood (m) }\end{array}$} & \multirow{2}{*}{$\begin{array}{c}\text { (4) } \\
\text { Maximum } \\
\text { scour depth } \\
d_{\mathrm{gs}}, \mathrm{d}_{\mathrm{bs}}(\mathrm{m}) \\
\end{array}$} & \multirow{2}{*}{$\begin{array}{c}(5)=(1)-(4) \\
\text { Riverbed level } \\
\text { for maximum I } \\
\text { scour depth } \\
\mathrm{H}\left(\mathrm{d}_{\mathrm{gs}}\right), \mathrm{H}\left(\mathrm{d}_{\mathrm{bs}}\right) \\
(\mathrm{m})\end{array}$} & \multirow{2}{*}{$\begin{array}{c}(6)=(2)-(5) \\
\begin{array}{c}\text { Deposited height } \\
\text { during falling } \\
\text { limb(m) }\end{array}\end{array}$} & \multicolumn{3}{|c|}{${ }^{\mathrm{a}}$ GPRS real-time scour monitoring } & \multirow[b]{2}{*}{ Note } \\
\hline & $\begin{array}{l}\mathrm{N} \\
(\mathrm{m})\end{array}$ & $\begin{array}{c}\mathrm{E} \\
(\mathrm{m})\end{array}$ & & & & & & & & & $\begin{array}{c}\text { Monitored } \\
\text { time }\end{array}$ & $\begin{array}{c}\text { Coed wireless } \\
\text { tracer } \\
(7)(\text { level of its } \\
\text { upper Brick m) }\end{array}$ & $\begin{array}{c}(8)=(1)-(7) \\
\text { Scouring } \\
\text { depth } \\
(\mathrm{m})\end{array}$ & \\
\hline $\begin{array}{c}\text { P1 } \\
\text { (general } \\
\text { scour) } \\
\end{array}$ & 2689695.943 & 211316.555 & \multirow{3}{*}{$\begin{array}{c}\text { Monsoon } \\
520 \\
(1: 50 \mathrm{am}, \\
2015 / 5 / 27)\end{array}$} & \multirow{3}{*}{$\begin{array}{l}801 \\
(6 \mathrm{~h})\end{array}$} & $\begin{array}{c}72.99 \\
\text { (Brick No.64) }\end{array}$ & 72.15 & -0.840 & $\begin{array}{c}0.840 \\
\mathrm{~d}_{\mathrm{gs}}\end{array}$ & $\begin{array}{c}72.15 \\
\text { (Brick } \\
\text { No.52) } \\
\end{array}$ & 0 & - & - & - & 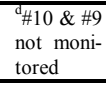 \\
\hline $\begin{array}{c}\text { P2 } \\
\text { (bridge } \\
\text { scour) }\end{array}$ & 2689738.213 & 211213.073 & & & $\begin{array}{c}69.49 \\
\text { (Brick No.64) }\end{array}$ & 68.71 & -0.785 & $\begin{array}{c}{ }^{\mathrm{c}} 0.785 \\
\mathrm{~d}_{\mathrm{bs}}\end{array}$ & $\begin{array}{l}{ }^{\circ} 68.71 \\
\text { (Brick } \\
\text { No.53) }\end{array}$ & 0 & $\begin{array}{l}{ }^{\mathrm{b}} 02: 43: \\
30\end{array}$ & $\begin{array}{c}\# 19 \\
(\text { Brick } \\
\text { No.57, El.= } \\
68.96) \\
\end{array}$ & 0.53 & $\begin{array}{l}{ }^{{ }^{A}} \# 20 \text { not } \\
\text { monitored }\end{array}$ \\
\hline $\begin{array}{c}\text { P3 } \\
\text { (general } \\
\text { scour) }\end{array}$ & 2689764.963 & 211152.107 & & & $\begin{array}{c}68.66 \\
\text { (Brick No.64) }\end{array}$ & 68.19 & -0.475 & $\begin{array}{c}0.475 \\
\mathrm{~d}_{\mathrm{gs}}\end{array}$ & $\begin{array}{c}68.19 \\
\text { (Brick } \\
\text { No.57) }\end{array}$ & 0 & - & - & - & $\begin{array}{l}{ }^{d} \# 30 \text { not } \\
\text { monitored }\end{array}$ \\
\hline
\end{tabular}

Note : ${ }^{a}$ GPRS system installed at downstream of left bank of the Highway Bridge ; ${ }^{\mathrm{b}}$ flood peak at 1:00 am for Shihkang Dam, distance $=18 \mathrm{~km}$, flood peak delay about $50 \mathrm{~min} ;{ }^{\mathrm{c}}$ if continuous wireless tracers installation, maximum scour can be monitored by real-time scour monitoring; ${ }^{\mathrm{d}}$ wireless tracer scoured out before the operation of GPRS system (installed well at 23:00 pm May 26, 2015). 
Figure 15 shows the signal strength indicator (RSSI) from wireless tracer \#17 monitored by the GPRS monitoring system. As shown in this figure, the maximum RSSI indicates that the distance between the mover end (wireless tracer \#17) and monitor end (GPRS system) was almost shortest. Accordingly, the received RSSI data of a floating wireless tracer by both monitor ends can be further used to compute the mean water surface velocity along the flow.

The mercury boot-up control of power supply was first tested to be used for the wireless tracers in the field site. Thus, the researcher can easily embed float-out devices into riverbed. However, the signals of the mover end might be unexpectedly unstable under an extremely turbulent flow. Therefore, several scoured wireless tracers were not monitored during this flood. The magnet boot-up control should be more suitable for the wireless tracer because it enables to keep on power supply after booting up by escaping the magnet (Yang \& Su, 2015).

Table 4. Variations of riverbed elevation for all measurement positions.

\begin{tabular}{cccc}
\hline \multirow{2}{*}{$\begin{array}{c}\text { Measurement } \\
\text { position }\end{array}$} & \multicolumn{2}{c}{ Riverbed elevation $(\mathrm{m})$} & $\begin{array}{c}\text { Variations } \\
(\mathrm{m})\end{array}$ \\
\cline { 2 - 3 } & 3/11 (before monsoon) & $7 / 23$ (after monsoon) & 0.42 \\
\hline P7 & 51.54 & 51.96 & 0.39 \\
\hline P6 & 51.81 & 52.20 & 0.31 \\
\hline P5 & 52.32 & 52.63 & -0.88 \\
\hline P4 & 57.28 & 56.40 & -0.50 \\
\hline P3 & 68.66 & 68.16 & -0.87 \\
\hline P2 & 69.49 & 68.62 & -0.86 \\
\hline P1 & 72.99 & 72.13 & \\
\hline
\end{tabular}

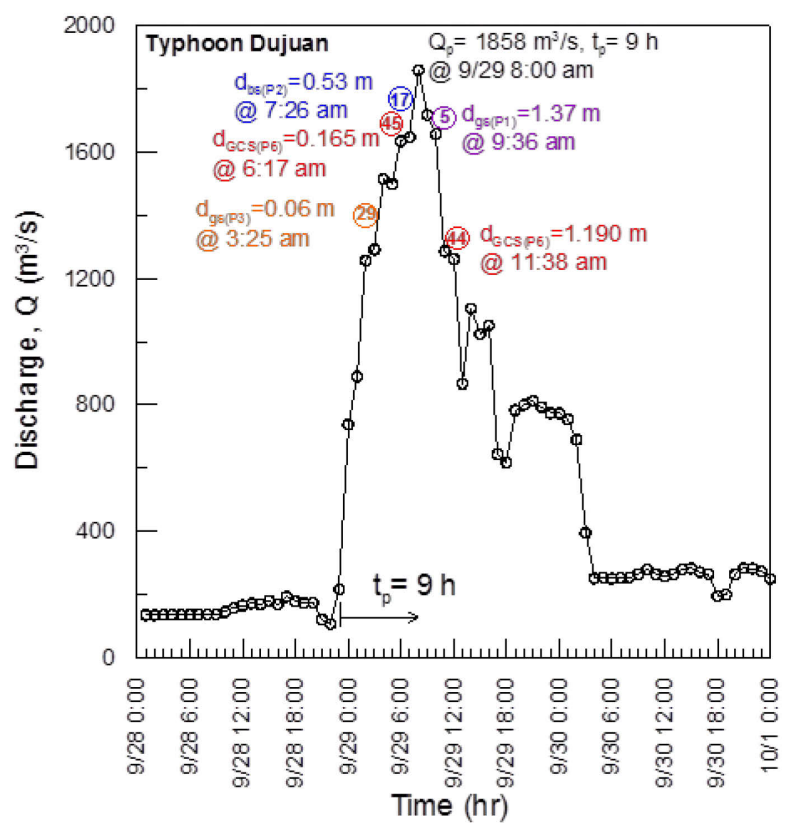

Figure 13. Flow discharge hydrograph and result of real-time scour monitoring during Typhoon Dujuan-induced flood.

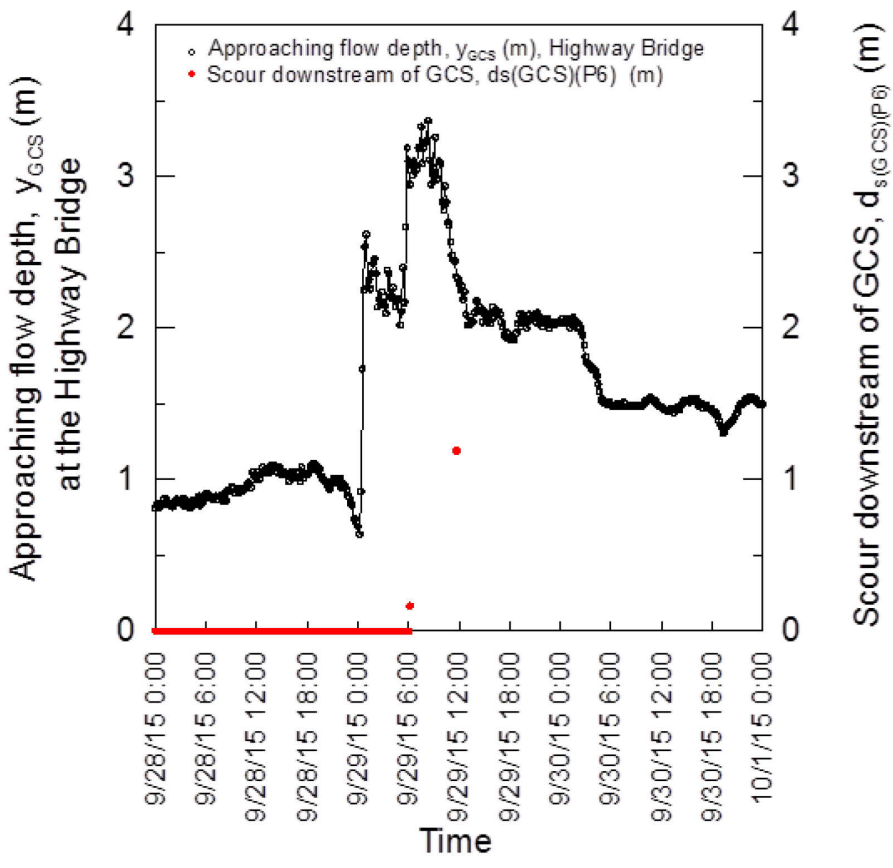

Figure 14. Comparison of approach flow depth at GCS and scour downstream of GCS around P6 measurement position during Typhoon Dujuan-induced flood.

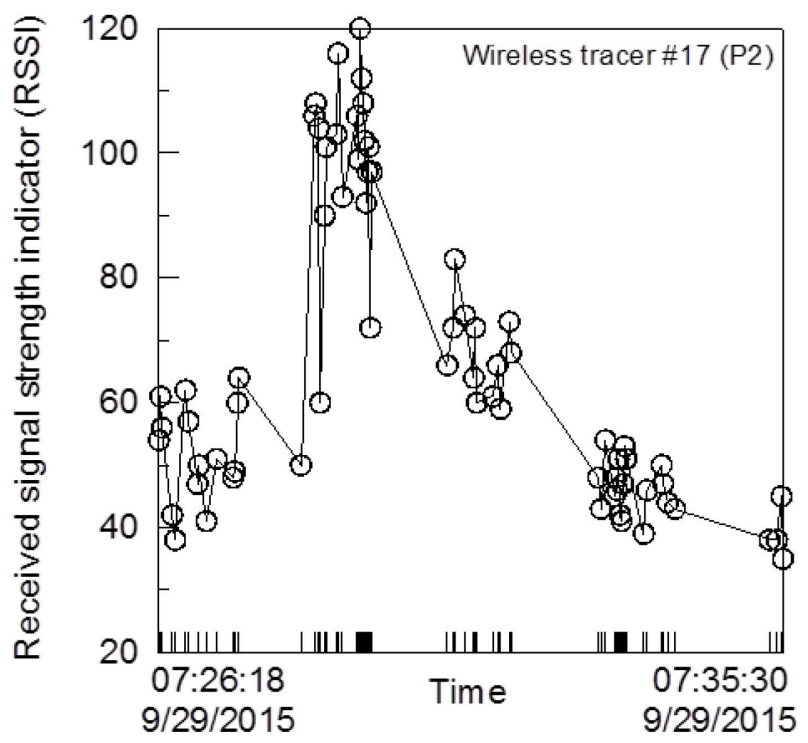

Figure 15. Monitored RSSI of Wireless tracer \#17 (embedded at P2).

The scoured flow depth can also be monitored synchronously using a real-time water surface level gauge for a bridge or embankment. The price of a single float-out device of a wireless tracer can be reduced through bulk purchasing of wireless module modems at a time. The maximum riverbed scour depth during a flood can be monitored by embedding continuous wireless tracers (resolution about $0.1 \mathrm{~m}$ ) vertically into the riverbed. 


\section{CONCLUSIONS}

Bridge and levee failures often caused by extreme short-time riverbed scouring events during monsoonor typhoon-induced floods in incised reaches after the long-term general scour/bed degradation in intermittent rivers in Taiwan. A wireless tracer GPRS real-time scour monitoring system developed in current study has monitored successfully general scour, bridge scour, bend scour, and scour downstream of GCS in the lower Dachia River during flood events in 2015.

The results indicate that the proposed method can be used as a potential tool for practical applications such as monitoring bridge and embankment performance, particularly during typhoon-induced flood events and provide early warning of failure risk. In future, it is expected that the scouring mechanism around the hydraulic structures in intermittent rivers in Taiwan can be thoroughly investigated. Moreover, the real-time dynamic scouring processes will provide valuable information for assessing sediment transport, the improvement of the hydraulic structure designs and the application of the landslide or debris flow warning system.

\section{ACKNOWLEDGEMENTS}

The authors would like to thank the Ministry of Science and Technology (under Contract MOST 1042625-M-366-001 and MOST 104-2811-M-005-028), Taiwan, for the financial support of this research. Also, the authors would like to thank the Water Resources Agency for the flow discharge data of the Shihkang Dam and water surface level data at the Highway Bridge.

\section{REFERENCES}

Anderson, N.L., Ismael, A.M., \& Thitimakorn, T. 2007. Ground-penetrating radar: a tool for monitoring bridge scour. Environmental \& Engineering Geosciences 13(1): 110.

Briaud, J.L., Hurlebaus, S., Chang, K.A., Yao, C., Sharma, H., Yu, O.Y., Darby, C., Hunt, B. \& Price, G. 2011. Realtime monitoring of bridge scour using remote monitoring technology, Technical Report FHWA/TX-11/0-6060-1, Austin, USA, http://tti.tamu.edu/documents/0-6060-1.pdf

Chen, G., Schafer , B., Lin, Z., Huang, Y., Suaznabar, O., Shen, J. \& Kerenyi, K. 2015. Maximum scour depth based on magnetic field change in smart rocks for foundation stability evaluation of bridges. Structural Health Monitoring 14(1): 86-99.

Emanuel, K.A. 2013. Downscaling CMIP5 climate models shows increased tropical cyclone activity over the 21 st century. Proc. Nat. Acad. Sci. 110, DOI/10.1073/pnas. 1301293110.

Gendaszek, A.S., Magirl, C.S., Czuba, C.R. \& Konrad, C.P. 2013. The timing of scour and fill in a gravel-bedded river measured with buried accelerometers. J. of Hydrol. 495: 186-196.

Hayden, J. \& Puleo, J. 2011. Near Real-Time Scour Monitoring System: Application to Indian River Inlet, Delaware. $J$. Hydraul. Eng., 10.1061/(ASCE)HY.1943-7900.0000399, 1037-1046.

Hong, J.H., Chiew, Y.M., Lu, J.Y., Lai, J.S. \& Lin, Y.B. 2012. Case study: Houfong Bridge failure in Taiwan. J. Hydraul. Eng., ASCE 138(2): 186-199.

Hunt, B.E. 2009. Monitoring of scour critical bridges. NCHRP Synthesis of Highway Practice 396, Transportation Research Board. Washington, D.C.

Kunkel, K.E. \& co-authors. 2013. Monitoring and understanding trends in extreme storms: state of knowledge. Bulletin of the American Meteorological Society 94, 499-514.

Lu, J.Y., Hong, J.H., Su, C.C., Wang, C.Y. \& Lai, J.S. 2008. Field measurements and simulation of bridge scour-depth variations during floods. J. Hydraul. Eng., ASCE 134(6): 810-821. [Closure of discussions, 2009, 135(11): 10181019]

Prendergast, L.J. \& Gavin, K. 2014. A review of bridge scour monitoring techniques. Journal of Rock Mechanics and Geotechnical Engineering, 6: 138-149.

Sheppard, D., Melville, B. \& Demir, H. 2014. Evaluation of existing equations for local scour at bridge piers. J. Hydraul. Eng., ASCE 140(1): 14-23.

Stringer, J., Lowe, L., Smidt, M. \& Perkins, C. 1998. Field guide to best management practices for timber harvesting in Kentucky. Cooperative Extension Service FOR-69. 71 p.

$\mathrm{Su}$, C.C. \& Lu, J.Y. 2013. Measurements and prediction of typhoon-induced short-term general scours in intermittent rivers. Natural Hazards 66(2): 671-687.

$\mathrm{Su}$, C.C. \& Lu, J.Y. 2016. Comparison of sediment load and riverbed scour during floods for gravel-bed and sand-bed reaches of intermittent rivers: case study. J. Hydraul. Eng., ASCE, 142(5), 10.1061/(ASCE)HY.1943-7900.0001119, 05016001 .

Svec, J.R., Kolka, R.K. \& Stringer, J.W. 2005. Defining perennial, intermittent, and ephemeral channels in Eastern Kentucky: Application to forestry best management practices. Forest Ecology and Management 214(1-3):170-182.

Wang, H.S., Hsieh, S.C., Lin, C. \& Wang, C.Y. 2014. Forensic diagnosis on flood-induced bridge failure. I: Determination of the possible causes of failure. Journal of Performance of Constructed Facilities 28(1): 76-84.

Washer, G.A. 2010. Long-term remote sensing system for bridge piers and abutments. Highway IDEA Project 123. 39 pp.

Wu, T.R., Wang, H.S., Ko, Y.Y., Chiou, J.S., Hsieh, S.C., Chen, C.H., Lin, C., Wang, C.Y. \& Chuang, M.H. 2014. Forensic diagnosis on flood-induced bridge failure. II: Framework of quantitative assessment. Journal of Performance of Constructed Facilities 28(1): 85-95.

Yang, H.C. \& Su, C.C. 2015. Real-time river bed scour monitoring and synchronous maximum depth data collected during Typhoon Soulik in 2013. Hydrological Processes 29(6): 1056-1068.

Yu, X., Yu, X. 2009. Time domain reflectometry automatic bridge scour measurement system: principles and potentials. Structural Health Monitoring 8(6): 463-476

Zarafshan, A., Iranmanesh, A. \& Ansari, F. 2012. VibrationBased Method and Sensor for Monitoring of Bridge Scour. J. Bridge Eng., 10.1061/(ASCE)BE.1943-5592.0000362, 829-838. 